\title{
A GIS Based Assessment of Selected Sites of Kota Barrage of Rajasthan with Special Reference to Water Quality Parameters
}

\author{
Dr. Kiran Choudhary ${ }^{1}$, Dr. Krishnendra Singh Nama ${ }^{2}$ \\ ${ }^{1}$ Department of Botany, M.B. PG College, Kota Rajasthan, India \\ ${ }^{2}$ Department of Life Science, Uni. Of Kota, Kota Rajasthan, India
}

\begin{abstract}
Present study revealed the physico-chemical characteristics of water quality in one sampling site at upstream and three sampling stations at downstream of Kota Barrage in different months of the year 2014-2015. pH fluctuates between 7.1 to 8.5 during the study period at all the sampling sites. Maximum value $(225.40 \mathrm{mg} / \mathrm{l})$ of alkalinity was observed during the month of February at Site III and minimum value $(86.00 \mathrm{mg} / \mathrm{l})$ was recorded in the month of July at Site I. The total hardness values ranged between $110.00 \mathrm{mg} / \mathrm{l}$ (upstream) to $220.00 \mathrm{mg} / \mathrm{l}$ (downstream). Highest value (105.00 mg/l) of calcium was observed at Site III (ds) and minimum (60.00 mg/l) values were recorded at Site I (us). Magnesium values ranged from a minimum of $30.00 \mathrm{mg} / \mathrm{l}$ at Site IV to a maximum of $75.00 \mathrm{mg} / \mathrm{l}$ at Site I in the month of May. Chloride is considered as pollution indicator when present in higher concentrations. Maximum value was recorded $100.00 \mathrm{mg} / \mathrm{L}$ at Site III and minimum value was observed $50.00 \mathrm{mg} / \mathrm{l}$ at Site I. Sulphate values ranged from a minimum of $20.00 \mathrm{mg} / \mathrm{l}$ at Site II in the month of July to a maximum of $70.50 \mathrm{mg} / \mathrm{l}$ at Site III in the month of May. Concentration of nitrates varied from $10.00 \mathrm{mg} / \mathrm{l}$ to $34.00 \mathrm{mg} / \mathrm{l}$. TDS ranged between $320.00 \mathrm{mg} / \mathrm{l}$ to $640.00 \mathrm{mg} / \mathrm{l}$. COD values were found to vary between $35.00 \mathrm{mg} / \mathrm{l}$ (upstream) to $91.50 \mathrm{mg} / \mathrm{l}$ (downstream). Maximum BOD value $(4.0 \mathrm{mg} / \mathrm{l})$ was recorded at site III and it was minimum (1.5 $\mathrm{mg} / \mathrm{l})$ at site $I$. Maximum value $(6.7 \mathrm{mg} / \mathrm{l})$ of DO was recorded at Site I during the month of October and minimum (2.7 mg/l) at Site I in the month of September. These results indicate that water of downstram is more polluted in summer months as compared to water of upstream sites.
\end{abstract}

Keywords: Physico-chemicals, upstream, downstream, pollution, indicator

\section{Introduction}

Life in an aquatic ecosystem is directly or indirectly depends on the water quality. The alteration in physico-chemical characteristics of water affect the biota in terms of number and diversity. Changes in the aquatic environment accompanying anthropogenic pollution are of great growing concern and require monitoring of surface water.

Kota divison is located in the south east part of the state of the Rajasthan at the edge of Malva plateau at $23^{\circ} 45^{\prime}$ to $25^{\circ} 53$ North latitudes and $75^{\circ} 9^{\prime}$ to $77^{0} 27$ 'East longitudes. The Chambal river flows through Kota city and several of its tributaries flow around the city. Several dams have been constructed on this river.

Kota Barrage is constructed on the Chambal river. Water of the Barrage is utilized to generate power, irrigation as well as for municipal supply. Looking to the significance and importance of such water bodies, present study was planned and carried out over a period of 12 months.

For the present study the study area was divided in upstream and downstream by taking one sampling station at upstream and three sampling stations at downstream of Kota Barrage. For this purpose GIS mapping was also used to indicate the study area (Figure-1).

\section{Study Sites}

Kota Barrage is situated within Kota city. After general survey four sampling sites were selected one at upstream and three at downstream of Kota Barrage.

1) Shajidehra (Sampling station I)

2) Kunari (sampling station II),

3) Kherli Purohit (sampling station III) and

4) Dadwara (sampling station IV) situated on the downstream of Kota Barrage. 


\section{International Journal of Science and Research (IJSR) \\ ISSN (Online): 2319-7064}

Index Copernicus Value (2013): 6.14 | Impact Factor (2015): 6.391

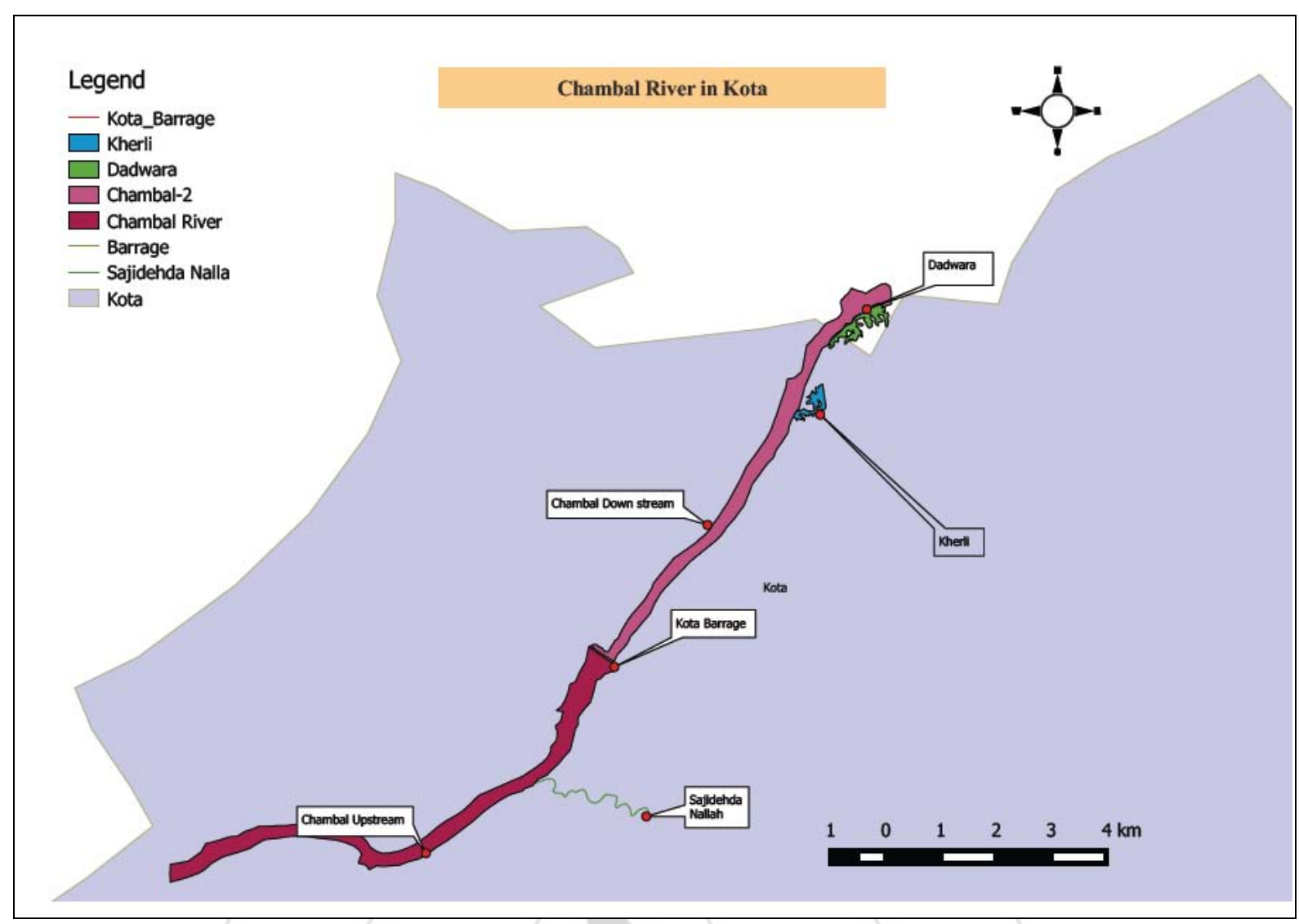

Figure 1: GIS Map of studied sites of River Chambal

\section{Material and Methods}

Water samples were analyzed up to one year (December 2014- December 2015) for physico-chemical analysis from four sampling sites of the Kota Barrage. Water samples were collected in two liter plastic bottles while separate water sample were collected for BOD in $250 \mathrm{ml}$ glass BOD bottles. Physico-chemical parameters were analyzed in the laboratory except temperature and $\mathrm{pH}$ which is monitored at the sampling sites with the help of thermometer and portable pen type $\mathrm{pH}$ meter respectively. All the physico-chemical parameters were analyzed including Colour, Chloride, Alkalinity, Total Hardness, Calcium, Magnesium, Sulphate, Nitrate, TDS, COD, BO), DO were analyzed.

\section{Result And Discussion}

\section{Temperature}

Atmospheric and water temperature both exert profound direct or indirect influence on metabolic and physiological behavior of aquatic ecosystems (Welch, 1952). Temperature at all the sampling station during the course of study was recorded $25^{\circ} \pm 5$

\section{Turbidity}

Turbidity is the status of water in respect of suspended particles in water. Maximum turbidity observed in the months of July and August at all the sites due to the addition of muddy rain water and phytoplankton density and minimum turbidity was observed in the winter months.

\section{pH}

Hydrogen ion concentration $(\mathrm{pH})$ fluctuate between 7.1 to 8.5 during the study period at all the sampling sites. Its lowest value (7.1) was recorded in the month of July at Site IV and highest in the month of September at the same site. Variation in $\mathrm{pH}$ value fluctuated narrowly between normal to slightly alkaline border. It is assumed that $\mathrm{pH}$ is regulated by carbon dioxide and bicarbonate. Water bodies with slightly alkaline $\mathrm{pH}$ are considered to maintain the good production in an aquatic ecosystem (Huet, 1971).

\section{Total Alkalinity}

Total alkalinity of water of Kota Barrage at selected sampling sites was ranged between $86.00 \mathrm{mg} / \mathrm{l}$ to 225.40 $\mathrm{mg} / \mathrm{l}$. Maximum value $(225.40 \mathrm{mg} / \mathrm{l})$ was observed during the month of February at Site III. The minimum value of total alkalinity $(86.00 \mathrm{mg} / \mathrm{l})$ was recorded during the month of July at Site I. Table 1-4 reveals that slightly higher values were recorded during summer season. Das and Pathani (1978) stated that total alkalinity indicates polluted water body. Site III seems be slightly polluted on the basis of values of total alkalinity. Higher values of alkalinity at this site might be due to agricultural runoff and domestic waste.

\section{Total Hardness}

Hardness of water is the indication of suitability of its use in drinking, washing, cooking and other domestic purposes. Hardness in water is caused by metallic ions dissolved in water. Table 1-4 shows the monthly variation in the amount of total hardness of Kota Barrage water at all the sites. The total hardness values ranged between $110.00 \mathrm{mg} / \mathrm{l}$ to 220.00 $\mathrm{mg} / \mathrm{l}$. Highest value $(220.00 \mathrm{mg} / \mathrm{l})$ was recorded at Site III during the month of June and lowest value $(110.00 \mathrm{mg} / \mathrm{l})$ 


\section{International Journal of Science and Research (IJSR) \\ ISSN (Online): 2319-7064}

Index Copernicus Value (2013): 6.14 | Impact Factor (2015): 6.391

was recorded during monsoon season. Higher values at this site indicates the higher pollution level because of ion concentration. Das Gupta and Purohit (2000) are of the opinion that the concentration of hardness increases towards the post monsoon season and decreases towards monsoon season. In the present study also a similar trend of hardness was noticed. Addition of rain water during monsoon might be the reason of its lower values in rainy season. This supports the findings of Pandit (1986).

\section{Calcium}

Table 1-4 exhibit the monthly variation in the amount of calcium which ranged between $60.00 \mathrm{mg} / \mathrm{l}$ to $105.00 \mathrm{mg} / \mathrm{l}$. Highest value $(105.00 \mathrm{mg} / \mathrm{l})$ of calcium was observed during the month of December at Site III and minimum $(60.00$ $\mathrm{mg} / \mathrm{l})$ values were recorded during the months of July and September at Site I. Nutrients, current and human activities impart on the amount of calcium hardness (George, 1966). Lower amount of calcium during monsoon season might be caused by greater dilution due to addition of rainwater which supports the findings of Singh (1985).

\section{Magnesium \\ Magnesium values ranged from a minimum of $30.00 \mathrm{mg} / \mathrm{l}$ at Site IV in the month of March to a maximum of $75.00 \mathrm{mg} / \mathrm{l}$ at Site $\mathrm{I}$ in the month of May. It is main reason causing water hardness. Its higher concentrations reduce the utility of water for domestic use and make it unfit for drinking purposes. Higher concentration of magnesium has been proven to be diuretic.}

\section{Chloride}

Chloride metabolically depicts pivotal role in photolysis of water and phosphorylation in autotrophs. It is considered as pollution indicator when present in higher concentrations. Maximum value was recorded $100.00 \mathrm{mg} / \mathrm{L}$ in the month of May at Site III and minimum value was observed $50.00 \mathrm{mg} / \mathrm{l}$ at Site I in the month of August during present study period. Lower values in the monsoon may be due to increase in water level caused by rains. Its maximum content was observed during summer. This was in accordance with Mahananda et. al. (2005). Values of chloride content in the water of study area are under the permissible limits. Chloride value can be influenced by weathering of soil and rocks, atmospheric precipitation environmental factors and pollution sources like industrial and municipal waste water (Ownbey and Kee, 1967).

\section{Sulphate}

Sulphate values ranged from a minimum of $20.00 \mathrm{mg} / \mathrm{l}$ at Site II in the month of July to a maximum of $70.50 \mathrm{mg} / \mathrm{l}$ at Site III in the month of May. Maximum values were recorded during summer months and minimum during rainy season. The present observation finds support with the work of Kannan (1991). In the present study sulphate at all the four sites was below permissible limit i.e., $250 \mathrm{mg} / \mathrm{l}$. A high concentration of sulphates stimulates the action of sulphur reducing bacteria which produce hydrogen sulphide, a gas highly toxic to fish life and high concentration of sulphate associated with the depletion of oxygen led to anoxic and anaerobic conditions in the water body.

\section{Nitrate}

Higher values of nitrate indicate pollution in the water body. During study period, concentration of nitrates varied from $10.00 \mathrm{mg} / \mathrm{l}$ to $34.00 \mathrm{mg} / \mathrm{l}$. Highest value of nitrate $(34.00$ $\mathrm{mg} / \mathrm{l})$ was observed at Site IV in the month of November. Minimum value $(10.00 \mathrm{mg} / \mathrm{l})$ was observed at Site III during the month of August. In the study area matters of organic origin is probably the cause for higher concentration of nitrates. Drainage of water through soil containing domestic and industrial wastes, vegetable and animal matter, garbage dump disposal may also be responsible for the high nitrate content. The mineralization of rainfall is found to be responsible for increasing the amount of nitrate in water. The presence of excessive nitrate in water is due to manmade domestic activities and fertilizers from fields (Zutshi and Vass, 1978). Nitrate content is within the permissible limits when compared to BIS permissible limits of $50 \mathrm{mg} / \mathrm{l}$ at all sampling sites during the study period.

\section{Total Dissolved Solid (TDS)}

Total dissolved solids ranged between $320.00 \mathrm{mg} / \mathrm{l}$ to 640.00 $\mathrm{mg} / \mathrm{l}$. Highest value $(640.00 \mathrm{mg} / \mathrm{l})$ was observed at Site IV in the month of June. Lower values were observed during winter season. The TDS values exhibited an increasing trend in post monsoon season owing to the reason that during post monsoon season dissolution of more quantity of constituents of soil particles takes place as ground water table increases during these months. The total dissolved solids values in water body are largely depend upon various nutrients and biotic activities.

\section{Chemical Oxygen Demand (COD)}

COD values in the water indicate that the water needs more oxygen to stabilize organic substances or rapid oxidative degradation. In this process it consumes dissolved oxygen. COD values were found to vary between $35.00 \mathrm{mg} / \mathrm{l}$ to 91.50 $\mathrm{mg} / \mathrm{l}$. Maximum value $(91.50 \mathrm{mg} / \mathrm{l})$ was recorded at site IV during the month of April and that of minimum (35.00 mg/l) at site I during the month of November. Higher values of COD were recorded during the summer season. Higher values indicate evaporation of water during summer and lower values during rainy and winter season due to dilution by rain water. Higher values during summer months may be due to high temperature (Kulshreshtha et al 1992 b). The recorded values suggested that during the course of investigation at all four sides the COD values were much above the permissible limits of $20 \mathrm{mg} / \mathrm{l}$. The higher COD values at Site IV might be due to continuous discharge of sewage and other allochthonous materials in the water.

The effluent having higher COD values will disturb or even destroy the aquatic life, thus harnessing the productivity of the aquatic ecosystem (Jain and Agarwal, 1989).

\section{Biological Oxygen Demand (BOD)}

BOD is defined as the amount of oxygen required by micro organisms to stabilize biologically decomposable organic matter in a waste, under aerobic conditions. BOD values ranged between $1.5 \mathrm{mg} / \mathrm{l}$ to $4.0 \mathrm{mg} / \mathrm{l}$ during the present study in the study area. Maximum BOD value (4.0 $\mathrm{mg} / \mathrm{l})$ was recorded at site III during the month of May and it was minimum $(1.5 \mathrm{mg} / \mathrm{l})$ at site I during the month of July. BOD 


\section{International Journal of Science and Research (IJSR) \\ ISSN (Online): 2319-7064 \\ Index Copernicus Value (2013): 6.14 | Impact Factor (2015): 6.391}

and other microbial activities in the water bodies are increased by introduction of sewage waste.

\section{Dissolved Oxygen (DO)}

DO is an important parameter to Judge the quality of water. Concentration and distribution of DO forms basis for proper understanding of aquatic ecosystem. It is essential for the metabolism of all aquatic organisms which perform aerobic respiration.

DO values ranged between $2.7 \mathrm{mg} / \mathrm{l}$ to $6.7 \mathrm{mg} / \mathrm{l}$. Maximum value $(6.7 \mathrm{mg} / \mathrm{l})$ was recorded at Site I during the month of October and minimum $(2.7 \mathrm{mg} / \mathrm{l})$ at Site $\mathrm{I}$ in the month of September. DO values in natural and waste waters are depend on the physical, chemical and biochemical activities prevailing in the water body. Lower values of DO indicates the poor trophic status of water body. Lower amount of DO at Site IV might be due to the standing state of water least water current, greater decomposition and increased respiration by heterotrophic organisms, which is in conformity with findings of Saha and Chaudhary (1985).

\section{Conclusions}

The concentration of major physico-chemical parameters exhibited an increasing trend during post monsoon season as compared to pre monsoon season. This is attributed to the dissolution of salts and minerals in soil through the recharge of groundwater by rainfall and rising the water table during the monsoon season.

Large scale anthropogenic activities, dumping of solid waste and discharge of waste water have resulted in getting water polluted. Pollution was comparative more in the downstream area. To avoid future hazardous effects on the environment, effective pollution control measures must be taken. Legislation should be framed against anthropogenic activities.

Last but not the least; nothing can be achieved without participation of people, voluntary organizations, institutions and pressure groups which play an important role in framing and implementation of government policies. This will ensure stopping of further harm to aquatic bodies effectively.

\section{References}

[1] Das, S.M. and Pathani, S.S. 1978. A study on the effect of lake ecology on productivity of Mahaseer (Tortor and Tor- putitora) in Kumaon lakes, India, Matsya 4 :25-31.

[2] Das Gupta, Adok M. and K. M. Purohit. 2000. Correlation coefficient of some physico-chemical characteristics of surface and ground waters of Rajgangapur. Part I Indian. J. Env. Prot. 20 : 681-686.

[3] George, M.G. 1966. Diurnal variations in physicochemical factors and zooplankton in the surface layers of three fresh water pond. Ind. J. Fisheries 13 : 48-82.

[4] Huet. M. (1971). Text book of culcutre, breeding and cultivation of fish. Fishing news Ltd. Survey.

[5] Jain, R.K., A.K. Agarwal. 1989. Water pollution due to saree printing industry effluents. Acta Ecol. 11 : 50-54.

[6] Kannan, K. 1991. Fundamentals of Environmental Pollution. S. Chand and Company Ltd., New Delhi.

[7] Kulshreshtha, S.K., Adholia, U.N. and Bhatnagar, A. 1992 b Zooplankton community of river Chambal and its tributaries with special reference to industrial polluction. Intern. J. Env. Stud. 40 : 207-216.

[8] Mahananda, B.H., M.R. Mahananda and B.P. Mohanty. 2005. Studies on the physico-chemical and biological para meters of a fresh pond ecosystem as an indicator of water polluction. Ecology :, Envirnment and conservation II (3-4) : 537-541.

[9] Ownbey, C.R. and D.A. Kee. 1967. Chlorides in Lak Erie. Proc. conf. Great lakes Res. Int. Assoc. Great Lakes Res 10 : 382- 389.

[10] Pandit, B. 1986. A Comparative Study of pond and reverine ecosystan stress. Ph.D. thesis. Bhag. Uni.I Bhagalpur, India.

[11] Saha. L.C. and H. K. Chaudhary. 1985. Phytoplankton density in relation to abiotic factors of a pond at Bhagalpur Comp. Physiol. Ecol. 10 : 98-100.

[12] Singh, A.K., 1985. Physico-chemical and bacterial study of sewage water discharge into the river Ganga at Bhagalpur, India. Environ. and Ecol. 3 : 138-142.

[13] Welch, P.S. 1952. Limnology. Mc Graw Hill Book Co., New York. $2^{\text {nd }}$ ed. : pp. 536.

[14]Zutshi, D.P. and Vass, K.K. 1978. Limnological Studies on Dal lake. Chemical features. Indian J. Ecol. 5 (1) : 90-97.

Table 1: Monthly variations in physico-chemical parameters of Kota Barrage at Sajidahera (Site I)

\begin{tabular}{|c|c|c|c|c|c|c|c|c|c|c|c|c|c|c|}
\hline S.No. & Parameters & Unit & Sep. & Oct. & Nov. & Dec. & Jan. & Feb. & Mar. & Apr. & May & June & July & Aug. \\
\hline 1 & $\mathrm{pH}$ & & 7.8 & 7.8 & 8.0 & 8.1 & 8.2 & 8.2 & 8.3 & 8.2 & 8.4 & 8.4 & 7.5 & 7.8 \\
\hline 2 & Total Alkalinity & $\mathrm{mg} / \mathrm{l}$ & 90.00 & 92.00 & 95.10 & 95.00 & 98.00 & 95.00 & 100.0 & 108.0 & 115.2 & 120.0 & 86.00 & 88.00 \\
\hline 3 & Total Hardness & $\mathrm{mg} / \mathrm{l}$ & 130.0 & 120.0 & 123.0 & 122.0 & 130.0 & 155.2 & 160.0 & 160.0 & 170.0 & 160.0 & 110.0 & 110.0 \\
\hline 4 & Calcium & $\mathrm{mg} / \mathrm{l}$ & 60.00 & 70.00 & 61.00 & 61.25 & 71.00 & 83.15 & 85.00 & 80.00 & 90.00 & 80.00 & 60.00 & 62.00 \\
\hline 5 & Magnesium & $\mathrm{mg} / \mathrm{l}$ & 50.00 & 50.00 & 62.00 & 60.75 & 59.00 & 52.05 & 65.00 & 75.00 & 60.00 & 60.00 & 50.00 & 48.00 \\
\hline 6 & Chloride & $\mathrm{mg} / \mathrm{l}$ & 60.00 & 60.00 & 62.40 & 63.10 & 63.00 & 65.18 & 65.00 & 70.00 & 72.00 & 74.00 & 60.00 & 50.00 \\
\hline 7 & Sulphate & $\mathrm{mg} / \mathrm{l}$ & 35.00 & 37.10 & 35.50 & 40.00 & 54.00 & 39.00 & 42.00 & 50.00 & 34.00 & 38.00 & 30.00 & 34.00 \\
\hline 8 & Nitrate & $\mathrm{mg} / \mathrm{l}$ & 20.00 & 22.00 & 18.00 & 20.00 & 24.00 & 20.00 & 26.00 & 25.00 & 32.00 & 30.00 & 18.00 & 20.00 \\
\hline 9 & TDS & $\mathrm{mg} / \mathrm{l}$ & 390.0 & 384.0 & 370.0 & 340.0 & 355.0 & 320.0 & 344.0 & 408.0 & 400.0 & 420.0 & 380.0 & 372.0 \\
\hline 10 & COD & $\mathrm{mg} / \mathrm{l}$ & 45.00 & 50.00 & 35.00 & 42.00 & 42.40 & 44.20 & 41.70 & 55.00 & 53.12 & 54.00 & 42.00 & 40.00 \\
\hline 11 & BOD & $\mathrm{mg} / \mathrm{l}$ & 1.8 & 1.4 & 1.9 & 2.8 & 2.3 & 2.0 & 2.5 & 2.7 & 2.9 & 3.0 & 1.5 & 2.0 \\
\hline 12 & DO & $\mathrm{mg} / \mathrm{l}$ & 5.2 & 6.7 & 5.6 & 5.2 & 5.6 & 5.0 & 3.5 & 4.0 & 3.6 & 3.5 & 5.1 & 5.2 \\
\hline
\end{tabular}




\section{International Journal of Science and Research (IJSR) \\ ISSN (Online): 2319-7064 \\ Index Copernicus Value (2013): 6.14 | Impact Factor (2015): 6.391}

Table 2: Monthly variations in physico-chemical parameters of Kota Barrage at Kunari (Site II)

\begin{tabular}{|c|c|c|c|c|c|c|c|c|c|c|c|c|c|c|}
\hline S.No. & Parameters & Unit & Sep. & Oct. & Nov. & Dec. & Jan. & Feb. & Mar. & Apr. & May & June & July & Aug. \\
\hline 1 & $\mathrm{pH}$ & & 8.1 & 8.0 & 7.7 & 8.0 & 8.3 & 8.2 & 8.0 & 7.9 & 8.4 & 8.3 & 7.4 & 7.7 \\
\hline 2 & Total Alkalinity & $\mathrm{mg} / \mathrm{l}$ & 110.0 & 115.10 & 135.20 & 120.2 & 143.9 & 134.7 & 140.0 & 141.7 & 138.4 & 143.0 & 147.4 & 120.0 \\
\hline 3 & Total Hardness & $\mathrm{mg} / \mathrm{l}$ & 130.0 & 140.00 & 120.20 & 134.4 & 145.0 & 140.2 & 150.3 & 145.2 & 148.0 & 152.0 & 110.2 & 120.0 \\
\hline 4 & Calcium & $\mathrm{mg} / \mathrm{l}$ & 70.00 & 72.20 & 68.70 & 77.40 & 78.30 & 75.20 & 82.40 & 98.00 & 78.00 & 92.15 & 68.40 & 70.25 \\
\hline 5 & Magnesium & $\mathrm{mg} / \mathrm{l}$ & 60.00 & 56.40 & 47.10 & 49.00 & 46.10 & 51.90 & 52.40 & 55.20 & 48.00 & 46.00 & 40.00 & 45.00 \\
\hline 6 & Chloride & $\mathrm{mg} / \mathrm{l}$ & 70.00 & 64.00 & 66.40 & 63.70 & 70.20 & 67.10 & 65.00 & 70.40 & 72.10 & 80.15 & 55.00 & 59.00 \\
\hline 7 & Sulphate & $\mathrm{mg} / \mathrm{l}$ & 37.00 & 18.00 & 30.10 & 35.40 & 20.20 & 50.50 & 40.20 & 60.30 & 60.40 & 40.00 & 20.00 & 35.40 \\
\hline 8 & Nitrate & $\mathrm{mg} / \mathrm{l}$ & 18.00 & 18.00 & 20.10 & 22.50 & 15.20 & 19.40 & 20.40 & 22.10 & 26.10 & 22.40 & 15.50 & 12.10 \\
\hline 9 & TDS & $\mathrm{mg} / \mathrm{l}$ & 420.0 & 140.00 & 400.00 & 320.0 & 360.0 & 370.4 & 410.0 & 465.0 & 540.0 & 500.0 & 430.0 & 435.0 \\
\hline 10 & $\mathrm{COD}$ & $\mathrm{mg} / \mathrm{l}$ & 75.00 & 74.00 & 73.00 & 64.00 & 69.00 & 72.00 & 76.00 & 74.20 & 80.40 & 70.80 & 70.00 & 65.00 \\
\hline 11 & BOD & $\mathrm{mg} / \mathrm{l}$ & 1.9 & 2.0 & 2.1 & 1.7 & 2.3 & 1.9 & 2.4 & 2.3 & 3.0 & 2.8 & 2.0 & 2.2 \\
\hline 12 & DO & $\mathrm{mg} / \mathrm{l}$ & 3.1 & 4.8 & 5.0 & 4.9 & 4.0 & 4.4 & 5.3 & 5.4 & 4.4 & 5.2 & 5.0 & 5.2 \\
\hline
\end{tabular}

Table 3: Monthly variations in physico-chemical parameters of Kota Barrage at Kherli Purohit (Site III)

\begin{tabular}{|c|c|c|c|c|c|c|c|c|c|c|c|c|c|c|}
\hline S.No. & Parameters & Unit & Sep. & Oct. & Nov. & Dec. & Jan. & Feb. & Mar. & Apr. & May & June & July & Aug. \\
\hline 1 & $\mathrm{pH}$ & & 8.2 & 7.8 & 8.1 & 7.7 & 8.2 & 8.0 & 8.2 & 7.9 & 7.5 & 8.0 & 7.3 & 8.0 \\
\hline 2 & Total Alkalinity & $\mathrm{mg} / \mathrm{l}$ & 170.0 & 180.4 & 165.10 & 175.0 & 200.0 & 225.4 & 220.0 & 215.5 & 170.0 & 180.0 & 160.0 & 175.0 \\
\hline 3 & Total Hardness & $\mathrm{mg} / \mathrm{l}$ & 120.00 & 130.0 & 125.50 & 140.0 & 217.0 & 180.0 & 210.0 & 170.0 & 200.0 & 220.0 & 205.5 & 200.5 \\
\hline 4 & Calcium & $\mathrm{mg} / \mathrm{l}$ & 80.00 & 70.50 & 90.50 & 105.0 & 90.00 & 89.00 & 100.7 & 76.70 & 68.90 & 78.00 & 72.70 & 80.75 \\
\hline 5 & Magnesium & $\mathrm{mg} / \mathrm{l}$ & 60.00 & 50.50 & 54.40 & 60.00 & 56.00 & 50.00 & 46.40 & 56.50 & 60.00 & 48.40 & 50.50 & 60.00 \\
\hline 6 & Chloride & $\mathrm{mg} / \mathrm{l}$ & 90.00 & 80.00 & 80.75 & 80.00 & 78.50 & 89.90 & 92.20 & 95.00 & 100.0 & 110.0 & 70.00 & 75.50 \\
\hline 7 & Sulphate & $\mathrm{mg} / \mathrm{l}$ & 50.00 & 55.20 & 50.00 & 52.00 & 50.50 & 51.70 & 60.70 & 65.00 & 70.50 & 70.00 & 50.00 & 55.00 \\
\hline 8 & Nitrate & $\mathrm{mg} / \mathrm{l}$ & 20.00 & 18.00 & 21.00 & 20.90 & 22.00 & 16.80 & 18.00 & 20.10 & 20.00 & 22.00 & 17.50 & 10.00 \\
\hline 9 & TDS & $\mathrm{mg} / \mathrm{l}$ & 440.00 & 400.5 & 390.00 & 420.0 & 400.5 & 425.7 & 410.0 & 480.0 & 500.0 & 520.0 & 410.0 & 400.8 \\
\hline 10 & COD & $\mathrm{mg} / \mathrm{l}$ & 65.00 & 60.60 & 64.50 & 40.50 & 70.40 & 45.40 & 60.10 & 72.50 & 50.10 & 60.50 & 60.20 & 70.10 \\
\hline 11 & BOD & $\mathrm{mg} / \mathrm{l}$ & 1.90 & 2.0 & 2.0 & 2.5 & 1.8 & 3.0 & 3.8 & 3.8 & 4.0 & 3.7 & 3.0 & 2.0 \\
\hline 12 & DO & $\mathrm{mg} / \mathrm{l}$ & 3.90 & 4.2 & 5.0 & 4.5 & 4.2 & 5.7 & 4.7 & 5.3 & 5.0 & 5.2 & 7.0 & 6.5 \\
\hline
\end{tabular}

Table 4: Monthly variations in physico-chemical parameters of Kota Barrage at Dadwara (Site IV)

\begin{tabular}{|c|c|c|c|c|c|c|c|c|c|c|c|c|c|c|}
\hline S.No. & Parameters & Unit & Sep. & Oct. & Nov. & Dec. & Jan. & Feb. & Mar. & Apr. & May & June & July & Aug. \\
\hline 1 & $\mathrm{pH}$ & & 8.5 & 8.2 & 7.0 & 7.5 & 7.6 & 8.4 & 8.2 & 8.3 & 8.0 & 7.3 & 7.1 & 7.5 \\
\hline 2 & Total Alkalinity & $\mathrm{mg} / \mathrm{l}$ & 120.50 & 125.5 & 130.00 & 135.4 & 127.4 & 140.0 & 140.0 & 142.5 & 147.2 & 120.0 & 115.0 & 110.0 \\
\hline 3 & Total Hardness & $\mathrm{mg} / \mathrm{l}$ & 110.00 & 120.5 & 115.50 & 120.0 & 125.0 & 117.0 & 140.0 & 143.5 & 200.0 & 150.0 & 150.0 & 130.0 \\
\hline 4 & Calcium & $\mathrm{mg} / \mathrm{l}$ & 60.00 & 75.20 & 70.00 & 81.20 & 80.70 & 75.00 & 70.50 & 82.50 & 70.00 & 80.50 & 82.40 & 70.90 \\
\hline 5 & Magnesium & $\mathrm{mg} / \mathrm{l}$ & 50.00 & 42.40 & 40.00 & 42.10 & 35.10 & 35.00 & 30.00 & 35.40 & 40.50 & 35.00 & 50.00 & 45.00 \\
\hline 6 & Chloride & $\mathrm{mg} / \mathrm{l}$ & 70.00 & 72.40 & 73.70 & 77.50 & 65.50 & 69.10 & 65.70 & 70.80 & 95.20 & 90.00 & 70.10 & 65.00 \\
\hline 7 & Sulphate & $\mathrm{mg} / \mathrm{l}$ & 45.00 & 48.40 & 55.00 & 50.00 & 39.40 & 55.00 & 35.70 & 57.50 & 43.00 & 50.00 & 35.00 & 42.50 \\
\hline 8 & Nitrate & $\mathrm{mg} / \mathrm{l}$ & 22.00 & 30.00 & 34.00 & 24.00 & 26.00 & 16.50 & 28.00 & 14.00 & 22.00 & 26.40 & 18.00 & 17.00 \\
\hline 9 & TDS & $\mathrm{mg} / \mathrm{l}$ & 510 & 490.5 & 520.00 & 500.5 & 540.0 & 470.0 & $\begin{array}{l}570.0 \\
\end{array}$ & 480.0 & \begin{tabular}{|l|l|}
610.0 \\
\end{tabular} & 640.0 & 510.0 & 500.0 \\
\hline 10 & COD & $\mathrm{mg} / \mathrm{l}$ & 70.00 & 64.70 & 71.50 & 66.50 & 75.50 & 61.50 & 90.00 & 91.50 & 72.50 & 70.50 & 80.00 & 70.00 \\
\hline 11 & BOD & $\mathrm{mg} / \mathrm{l}$ & 2.0 & 1.8 & 3.0 & 2.8 & 2.0 & 3.2 & 2.7 & 1.9 & 2.6 & 2.0 & 2.9 & 3.0 \\
\hline 12 & DO & $\mathrm{mg} / \mathrm{l}$ & 2.7 & 4.0 & 4.2 & 4.8 & 4.3 & 4.0 & 5.0 & 4.6 & 5.2 & 4.8 & 6.0 & 5.0 \\
\hline
\end{tabular}

